Does relationship marketing improve customer relationship satisfaction and loyalty?

Andreas Leverin ${ }^{1}$ and Veronica Liljander ${ }^{2}$

${ }^{1}$ Corresponding author. Doctoral student at the Centre for Relationship Marketing and Service Management (CERS), Swedish School of Economics and Business Administration, P.O. Box 479, 00101 Helsinki, Finland. Tel: +358-40-3521348, Fax: +358-9-43133287, Email: andreas.leverin@hanken.fi

${ }^{2}$ Professor, Head of Department of Marketing, Swedish School of Economics and Business Administration, P.O. Box 479, 00101 Helsinki. Tel: +358-40-3521288, Fax: +358-943133287, E-mail: veronica.liljander@hanken.fi

\title{
Autobiographical notes
}

Andreas Leverin (M.Sc. [Econ]) is currently a doctoral student at the Centre for Relationship Marketing and Service Management (CERS) at the Swedish School of Economics and Business Administration (Hanken), Helsinki, Finland. His main research focus is the management of customer relationships as assets in the retail banking sector.

Veronica Liljander is Professor of Marketing and Head of the Department of Marketing at the Swedish School of Economics and Business Administration (Hanken), Helsinki, Finland. Her current research interests include service and relationship marketing, consumer responses to electronic services, and private label marketing. She has published articles, for example, in the International Journal of Service Industry Management, Journal of Services Marketing, and Psychology \& Marketing. She is on the editorial board of several international journals, for example, European Journal of Marketing and Journal of Retailing and Consumer Services. 
Does relationship marketing improve customer relationship satisfaction and loyalty?

\begin{abstract}
Purpose - This study investigates the relationship marketing (RM) strategy of a retail bank and examines whether - after its implementation - customer relationships were strengthened through perceived improvements in the banking relationship and consequent loyalty towards the bank.
\end{abstract}

Design/methodology/approach - A survey was conducted on two profitability segments, of which the more profitable segment had been directly exposed to a customer oriented RM strategy, whereas the less profitable segment had been subjected to more sales oriented marketing communications.

Findings - No significant differences were found between the segments on customers' evaluations of the service relationship or their loyalty toward the bank. Furthermore regression analysis revealed that relationship satisfaction was less important as a determinant of loyalty in the more profitable segment.

Research limitations/implications - This study was conducted as a case study of one specific branch of a bank group in Finland, which limits the external validity of its results. It was not possible to ascertain if, or to what extent, customers of the more profitable segment had received the intended RM treatment. Other limitations are also discussed.

Practical implications - Customer orientation is desirable within retail banking and more studies are needed on the differential drivers of loyalty across customer profitability segments. By identifying the aspects of a banking relationship that are more highly valued among more profitable customers than among less profitable customers, bank managers would be able to more effectively devise appropriate strategies for different segments.

Originality/value - The study contributes to the RM literature and marketing of financial services by providing empirical evidence of the effects of RM activities on customer relationship perceptions in different profitability segments.

Keywords Relationship marketing, Customer relationship satisfaction, Customer loyalty, Segmentation, Retail banking

Article Type Research paper 


\section{Introduction}

Relationship marketing (RM) has been put forth as a way for firms to develop mutually beneficial and valuable long-term relationships with customers (Ravald and Grönroos, 1996). RM is believed to work most effectively when customers are highly involved in the good or service, there is an element of personal interaction, and customers are willing to engage in relationship building activities (O’Malley and Tynan, 2000). Customer oriented RM programmes that enhance the flow of information between the bank and customers increase customers' positive feelings towards their bank, thereby also increasing satisfaction and relationship strength (Barnes and Howlett, 1998; Ennew and Binks, 1996). Although past studies provide knowledge regarding the nature and importance of banking relationships from a customer (O’Loughlin et al., 2004), business (Madill et al., 2002), and dyadic (Paulin et al., 1998; Åkerlund, 2004) viewpoint, some questions remain unanswered. For example, we lack information on the extent to which specific RM programmes have succeeded in strengthening relationships in different segments.

RM can, but need not be, directed towards all customers of the bank. Most retail banks are characterised by having both profitable and unprofitable customers, where the former subsidise the latter (Carson et al., 2004; Zeithaml et al., 2001). Retaining the profitable customers has become increasingly difficult in a competitive environment where other financial institutions specialise in offering attractive services and prices to this lucrative segment. Since investments across all customer segments will not yield similar returns (Zeithaml et al., 2001), RM is often directed only at the most profitable segments defined by, for example, income and wealth (Abratt and Russell, 1999). There is, however, a lack of research on how RM activities affect relationship outcomes in the target segment. This is the focus of our study. 
The aim of this study is to investigate the RM strategy of a retail bank, in order to discover whether the implementation of the strategy has had the intended strengthening effect on customer relationships. A survey was conducted on two different profitability segments, collecting data on customer relationship satisfaction, perceived relationship improvement, and loyalty towards the bank. Of the two customer segments, the more profitable segment (Segment 1) was directly exposed to the RM programme, whereas the less profitable segment (Segment 2) was not.

The paper is structured as follows: The literature review outlines previous findings on relationship marketing, the interrelationship between customer relationship satisfaction and loyalty, and customer profitability segmentation. The empirical part of the paper describes the RM programme at the case bank, and the design, collection and analysis of survey data. The paper concludes with a discussion of the results, managerial implications, limitations of the study and suggestions for further research.

\section{Literature review}

\section{Relationship marketing}

Relationship marketing emerged in the 1980's as an alternative to the prevailing view of marketing as a series of transactions, because it was recognised that many exchanges, particularly in the service industry, were relational by nature (Berry, 1983; Dwyer et al., 1987; Grönroos, 1994; Gummesson, 1994; Sheth and Parvatiyar, 2000). Within a retail banking setting, Walsh et al. (2004, p. 469) define RM as "the activities carried out by banks in order to attract, interact with, and retain more profitable or high net-worth customers." Relationship marketing thus aims at increasing customer profitability while providing better services for customers. Several studies have empirically demonstrated a positive association between RM strategies and business performance (e.g. Naidu et al., 1999; Palmatier and Gopalakrishna, 2005). Within a banking context, Keltner (1995) found that German banks, in 
contrast to American banks, managed to maintain a stable market position during the 1980's and early 1990's as a consequence of relationship oriented banking strategies.

RM will not automatically lead to stronger customer relationships; rather, customers will exhibit different levels of relationship closeness and strength (Berry, 1995; Liljander and Strandvik, 1995). In order to be attractive, RM strategies should enhance customers' perceived benefits of engaging in relationships (O’Malley and Tynan, 2000). However, all customers do not want to engage in relationships and, in fact, it has been suggested that close customer relationships in banking are rare, and that they are being further weakened by the increase in self-service technologies (O'Loughlin et al., 2004). An alternative is to look upon new technologies as relationship facilitators (Sweeney and Morrison, 2004) and to use them strategically in customer relationship management (Payne and Frow, 2005).

One of the basic tenets of relationship marketing is customer orientation. Already the SOCO (selling orientation-customer orientation) scale, developed by Saxe and Weitz (1982), was based on the premise that customer oriented sales people strive to increase customers' longterm satisfaction. Selling oriented sales people were considered to prioritise the achievement of an immediate sale at the expense of customer needs. Subsequent research has shown that the degree of customer orientation indeed has an effect on a firm's relationships with its customers (Clark, 1997; Yavas et al., 2004). In a study of financial services, Bejou et al. (1998) found that customer oriented employees had a positive impact, while sales oriented employees had a negative impact, on customers' relationship satisfaction.

To our knowledge, there are no previous studies on the effect of RM activities on customer loyalty in different profitability segments. Before describing profitability segmentation, we will briefly review two desired relationship outcomes, customer relationship satisfaction and loyalty. 


\section{Customer relationship satisfaction}

Customer evaluation measures should reflect the type of exchange that is being evaluated, i.e. transactional or relational. Often used measures in a relationship context are relationship quality (e.g. Bejou et al., 1996; Crosby et al., 1990; Lang and Colgate, 2003), and relationship satisfaction (e.g. Abdul-Muhmin, 2002; Rosen and Surprenant, 1998). A positive relationship between service quality and satisfaction has been well established in the banking sector (e.g. Ennew and Binks, 1999; Jamal and Naser, 2002; Hooi Ting, 2004). However, the constructs are highly correlated and sometimes difficult to separate in transactional interactions (Bitner and Hubbert, 1994), but even more so from a relationship perspective (Dabholkar, 1995). In long-term relationships perceived quality and satisfaction are likely to merge into an overall evaluation of relationship satisfaction.

\section{Customer loyalty}

Customer loyalty is defined as "a deeply held commitment to rebuy or repatronize a preferred product/service consistently in the future, thereby causing repetitive same-brand or same brand-set purchasing, despite situational influences and marketing efforts having the potential to cause switching behaviour." (Oliver, 1999, p. 34).

As illustrated in the definition above, loyalty has both an attitudinal and behavioural dimension (Dick and Basu, 1994). It is assumed that customers who are behaviourally loyal to a firm display more favourable attitudes towards the firm, in comparison to competitors. However, in some cases behavioural loyalty does not necessarily reflect attitudinal loyalty, since there might exist other factors that prevent customers from defecting (Aldlaigan and Buttle, 2005; Liljander and Roos, 2002; Reinartz and Kumar, 2002).

Customer satisfaction and loyalty are highly correlated (Athanassopoulos et al., 2001; Hallowell, 1996; Silvestro and Cross, 2000), but form two distinct constructs (Bennett and Rundle-Thiele, 2004; Oliver, 1999). Customer satisfaction with a bank relationship is a good 
basis for loyalty (Bloemer et al., 1998; Pont and McQuilken, 2005), although it does not guarantee it, because even satisfied customers switch banks (Nordman, 2004). One important reason for switching is pricing (Colgate and Hedge, 2001; Ennew and Binks, 1999). Hence, banks have launched customer loyalty programmes that provide economic incentives. Although the effectiveness of loyalty programmes has been questioned (e.g. Dowling and Uncles, 1997; Sharp and Sharp, 1997; Stauss et al., 2005), research has shown that they have a significant, positive impact on customer retention, service usage, and/or share of customer purchases (e.g. Bolton et al., 2000; Verhoef, 2003).

The link between loyalty and profitability

Numerous studies have shown positive links between loyalty and firm profitability (Anderson et al., 1994; Hallowell, 1996; Reichheld, 1996; Silvestro and Cross, 2000). Nonetheless, not all loyal customers are profitable (Storbacka, 1994; 1997). According to Reinartz and Kumar (2002), the overall link between loyalty and profitability in many industries is questionable for two reasons: 1) a relatively large percentage of long-term customers are only marginally profitable, and 2) a relatively large percentage of short-term customers are highly profitable. It is noteworthy, however, that Reinartz and Kumar's (2002) findings from four industries (high technology, postal service, retail food and direct brokerage) still indicate that a larger proportion of the long-term customers than of the short-term customers exhibit high profitability, and a larger proportion of the high-profitability customers than of the lowprofitability customers are long-term customers. Thus, the theory of an overall positive connection between customer loyalty and profitability cannot be rejected. As noted by Anderson and Mittal (2000), customer relationship profitability arises through the acquisition and retention of "high quality" customers with low maintenance costs and high revenue. In the context of retail banking, Storbacka (1994) describes relationship costs as comprising direct variable costs, such as transaction related costs and costs related to specific 
services, in addition to overhead costs that may or may not be attributable to particular relationships. Relationship revenue, meanwhile, is split into volume-based revenue that is derived from interest margins, and fee-based revenue. Customers' patronage concentration (Storbacka, 1994), or share-of-wallet (Keiningham et al., 2003; Perkins-Munn et al., 2005), and pricing policies are important aspects of relationship revenue in banking. Since a large part of banks' revenues are received from interest margins, customers' volume of business has a major impact on profitability. If relationship costs are minimized and relationship revenue is maximized over time, long-term customers should generate greater profitability than shortterm customers.

\section{Profitability segmentation in banks}

Market segmentation is one of the central concepts in marketing, attributed to a seminal article by Smith (1956) in the Journal of Marketing. However, customer profitability as a segmentation criterion is a newer phenomenon (Storbacka, 1994). It has become increasingly predominant in many industries, leading to differential treatment of customers (Zeithaml et al., 2001).

In order to increase the profitability of customer relationships, Storbacka (1997) suggests applying the principles of segmentation in an RM context. The following segmentation criteria are proposed: 1) relationship revenue and relationship cost; 2) relationship volume; 3) relationship profitability, or 4) relationship volume and profitability. In an empirical study of two Nordic retail banks, Storbacka (1997) found that both banks opted for a segmentation based on relationship volume and profitability. Relationship volume was defined as the sum of the customer's yearly average deposit and loan balances, and absolute profitability was measured as the customer's relationship revenue minus relationship costs over a fiscal year. Six main segments were identified based on different levels of volume and profitability. The least attractive segment included the low volume, unprofitable customers. Storbacka (1997) 
recommends that efforts should be made to increase the volume of these customers, or impact the nature and/or price of transactions in order to increase relationship revenue and cut relationship costs. Similar recommendations are found in other studies (Zeithaml et al., 2001). The most attractive segment comprised high volume, profitable customers, a majority of whom represented a large portion of the total profitability of the customer base. Storbacka (1997) emphasises that customer defections from this group must be kept to an absolute minimum (optimally at a nonexistent level) in order to maintain and/or increase the profitability of the customer base. In a similar vein, Reinartz and Kumar (2003) suggest that customers can be grouped according to share-of-wallet and profitable lifetime duration, and that each customer group should be targeted with a specific strategy. In summation, relationship marketing activities should be directed particularly towards the most profitable customers in order to increase their satisfaction with and loyalty towards the bank. Therefore, in the case study, which is presented next, we expect that the high profitability segment that was targeted with a relationship oriented strategy will express higher relationship satisfaction and loyalty than the mid-profitability segment that was targeted with a more sales oriented strategy. Furthermore, we expect the perceived relationship improvements since the bank's RM strategy was launched, four to five years prior to the study, to be greater within the high profitability segment than within the midprofitability segment.

\section{Method}

The empirical study was conducted in 2003 at a member cooperative bank branch of the OP Bank Group (formerly the OKO Bank Group), one of the major bank groups in Finland. The case bank was chosen for this study because it had fully implemented an RM strategy that was first launched in 1998. Our case study examines the RM strategy and investigates whether its 
implementation has led to customer-perceived improvements in the banking relationship, and to increased loyalty in the targeted segment.

In line with the recommendations of Eisenhardt (1989), different methods were used to collect data. Primary and secondary data on the bank's RM strategy were first gathered from the bank's web site, annual reports, information brochures, seminar presentations by bank representatives, and interviews with the bank manager and staff. A survey was then designed to investigate customer relationship satisfaction, customer-perceived improvement in the relationship during the past four to five years, and customer loyalty towards the bank. The survey was directed towards two profitability segments. Customers in one of the segments had been exposed to a customer oriented RM strategy, whereas customers in the other segment had been subjected to a more sales oriented marketing strategy. Thus the aim was to investigate if the two segments differed in their perceptions of the bank relationship, or more precisely, if customers who had been exposed to the customer oriented RM strategy had more positive perceptions of the relationship.

The following sections describe the OP Bank Group's RM strategy, its segmentation of customers, and management's perceptions of the new approach. After this introduction of the strategy itself, the customer survey will be described and its results will be analysed. Relationship marketing and profitability segmentation at the bank

In 1997 the OP Bank Group started implementing a strategy with the purpose of becoming the leading bank in Finland. The strategy was referred to as a customer oriented way of working (Osuuspankkilehti, 1997). In 2000, the strategy was revised in response to changes in technology and competition. Three benchmarks of success were established, namely performance in customer relations, internal performance, and financial performance. The main benefit of concentrating banking affairs at the bank group is the collection of bonus points within a kind of customer loyalty programme. Bonus points are awarded based on the 
amount of monthly deposits, loans (including credit), and mutual fund investments. The bonus points can be used as payment for many of the bank's service fees. In 2003 the programme was revised, allowing customers to receive cash payments corresponding to the number of bonus points they collect.

The OP Bank Group and, consequently, also the bank in this study internally divide customers into three segments, here referred to as Segment 1, Segment 2, and Segment 3. The segmentation is part of the RM strategy that was launched by the bank in 1998 and that began to be implemented in late 1998 and early 1999. The main criteria for segmenting customers are contribution (i.e. profitability) and volume (loans, deposits, and investments). In addition, customer wealth is a criterion for Segment 1 and age is an additional criterion for Segments 2 and 3. Customers in Segment 1 are the bank's most profitable customers, or have the highest business volume or wealth. Customers in Segment 2 have a certain volume or profitability (less than Segment 1), or are younger than 26 years old. Segment 3 customers are at least 26 years old, have a smaller volume than the other segments and are less profitable than the other segments.[1] The age criterion is used because young customers often have not been able to reach high levels of volume, profitability, or wealth, but may hold great potential for the future. At the time of the study, 5.9\% of the case bank's private customers belonged to Segment 1, 56.1\% belonged to Segment 2, and 38.0\% belonged to Segment 3. The customers themselves do not know which segment they belong to.

Segment 1 customers are priority customers of the bank, which has adopted a customer oriented strategy towards these customers, based on the principles of relationship marketing. Each qualified front-line employee at the bank is responsible for a number of these customers. Lists of customers who currently fulfil the criteria for the segment, as well as of those who no longer fulfil the criteria, are compiled monthly. The goal for 2003 was to map the needs of 
$80 \%$ of the customers in Segment 1 and a bonus system was introduced to motivate the staff to reach the objective.

In order to map each Segment 1 customer's needs, these customers are contacted by telephone and offered a personal appointment with the bank employee to discuss current and possible future needs. The aim is to keep continuous contact with each customer, approximately twice per year. Customers that visit the bank at least twice a year are asked by contact employees how satisfied they are with the bank and its services. Customers that seldom visit the bank office are contacted by telephone. By offering additional services during these contacts (crossselling) the bank also strives to increase the profitability of each customer relationship. Segment 2 customers, meanwhile, are exposed to a sales oriented strategy whose objective is to increase the long-term savings of customers in this segment. These customers are contacted by telephone and offered different types of long-term savings, such as mutual funds. However, they are not offered personal appointments and no continuous contact is kept with these customers in order to map their needs.

Segment 3 customers are generally unprofitable, or only marginally profitable, and the bank's goal is to increase their profitability, or at least decrease their unprofitability. The bank directs a transaction oriented strategy towards these customers, minimizing the amount of time spent on them and encouraging them to use self-service options, such as online banking, thus aiming to reduce the relationship costs. The bank also attempts to increase relationship revenue from these customers by increasing their volume, for example, by offering loans. Management perceptions of the RM strategy

According to the bank manager, the main change that has occurred as a result of the more customer oriented strategy is that the bank is now responsible for establishing and maintaining contact with customers, whereas formerly this used to be up to the customer. The continuous contact entails gathering and storing information about customers for use in future 
contacts. A deeper customer relationship is also established with Segment 1 customers. The manager claims that the strategy has resulted in higher volumes of loans, deposits, and investments.

Educating front-line employees in the new ways of working with customers was not always easy, according to the manager. As personal contacts for Segment 1 customers, employees are now required to be more knowledgeable about a wider range of products than before. Moreover, employees were not used to actively contact customers and did not immediately feel comfortable doing it. Individual and group bonuses are used as incentives. According to the manager, a potential problem in having a personal contact at the bank might be that customer satisfaction or dissatisfaction is too closely tied to the contact person, taking attention away from the quality of the service products.

Survey design

A survey was designed to capture customer-perceived relationship satisfaction, perceived relationship improvement and loyalty towards the bank. To gain further insight, three customers (two from Segment 1 and one from Segment 2) were interviewed about their bank relationship. Their comments on a preliminary version of the questionnaire were also sought. The final questionnaire consisted of fifteen declarative statements, with five-point Likert-type scales, ranging from completely disagree to completely agree. The statements were constructed for this study and the length of the survey was restricted to increase the response rate.

As previously noted, there is little difference between satisfaction and quality in an ongoing relationship and our measures of customer relationship satisfaction are akin to what others have called relationship quality (Roberts et al., 2003). The measures included customer trust and satisfaction (Roberts et al., 2003), handling of critical incidents (Liljander and Strandvik, 1995; Michel, 2004), and perceived economic benefits in the form of a bonus programme. 
Although a number of studies have examined, for example, the effect of changes in satisfaction on behavioural intentions over time (Mazursky and Geva, 1989; Mittal et al., 1999; Verhoef et al., 2002), to our knowledge, no previous studies have measured customer perceptions of relationship improvement. Four measures were constructed to tap into customers' perception of changes in their bank relationship. Customer loyalty was measured as self-expressed loyalty, using well-established items, such as switching and recommendation intentions, in addition to an item capturing self-stated share-of-wallet, a rare measure in retail banking studies (Baumann et al., 2005). One background question on relationship length, measured in number of years, was included as a single measure of actual behavioural loyalty. Data on customers' age and gender were also collected. An open-ended question was included at the end, seeking additional comments from the respondents. A total of 70 respondents $(21.9 \%)$ added handwritten comments.

\section{Data collection}

The study was conducted in June 2003 on a random sample of 947 customers, consisting of approximately an equal number of Segment 1 and Segment 2 customers. Segments 1 and 2 were chosen, because these segments were the most important for the bank. They also differed on the type of customer relationship strategy used by the bank to maintain and enhance relationships: a customer oriented strategy for Segment 1 and a sales oriented one for

Segment 2. Segment 3, which included the most unprofitable customers who were not exposed to any particularly active strategy, was not included in the survey. The approximate equal number of questionnaires sent to Segment 1 and Segment 2 allows for easier comparison between the groups than if a proportional sample had been used, since the proportion of customers in Segment 1 was only 5.9\% compared with 56.1\% in Segment 2. A random sample was generated with the aid of a computer programme. Only customers who were at least 20 years old, resided in Finland, and who were not employed by the bank, or a 
member of the board, were included in the sample. The questionnaire was sent to $443(46.8 \%)$ customers from Segment 1 and 504 (53.2\%) from Segment 2. They received the questionnaire with a cover letter that encouraged participation (Peterson, 2000), and assured complete confidentiality of the responses.

A total of 345 questionnaires were returned, of which 26 were discarded as incomplete. The remaining 319 represent $33.7 \%$ of the sample, which can be considered high for a mail survey, where a $20 \%$ rate is common (Fink, 1995). The response rate per segment was even, resulting in 146 respondents belonging to Segment 1 (45.8\%) and 173 respondents belonging to Segment $2(54.2 \%)$. A profile of the respondents, which accurately reflects the characteristics of the bank's customer base, is displayed in Table I.

Take in Table I

\section{Survey Findings}

In general, the mean average scores of all 319 responses were quite high, ranging from 3.45 to 4.38 on a 5-point scale (Table II). The mean scores for perceived improvement over the past 4-5 years also indicate that customers had perceived improvements in their relationship with the case bank. However, contrary to expectations, independent t-tests revealed no significant differences between Segment 1 and Segment 2 on any of the items. It should be noted that the data was not normally distributed. Many of the items were negatively skewed and peaked, in particular items (1) and (4). Customers' average length of relationship with the bank (Table I) was also similar between the segments $(\mathrm{p}=0.869)$.

Before proceeding to explore differences in the interrelationships between constructs, the items were factor analysed. The Kaiser-Meyer-Olkin (KMO) value of 0.922 was high (Kaiser and Rice, 1974) and indicated that the data were suitable for factor analysis. Principal component factor analysis with Varimax rotation yielded the three expected factors, together explaining $57.59 \%$ of the variance. Two statements on customer needs were removed because 
they did not load highly on any of the factors, or form a factor of their own. The retained items (marked with an asterisk in Table II) loaded clearly and highest on the expected constructs. Cronbach's alphas for all three constructs were above 0.7 , which is considered adequate construct reliability (Hair, Jr. et al., 1998).

\section{Take in Table II}

A vital question was if the implementation of a relationship marketing strategy on Segment 1 customers had any differential effect on customer loyalty, compared with Segment 2 customers. Although no significant differences were found between the item means of Segment 1 and Segment 2 customers, it is necessary to identify any differences between the two segments with regards to the antecedents of loyalty.

In order to determine differences between Segment 1 and Segment 2 customers regarding the relative impact of relationship satisfaction and perceived improvements in the relationship on customer loyalty, regression analyses were conducted. To avoid collinearity effects, a new factor analysis was conducted on the nine variables forming Customer relationship satisfaction and Relationship improvement, and the resulting uncorrelated factor scores were used as independent variables in the regressions. The regression results are summarised in Table III.

Take in Table III

The results show that loyalty in both segments depends more on the current level of relationship satisfaction than on perceived relationship improvements. It is also notable how similar the effects of perceived relationship improvement are in both segments. Furthermore, a comparison between explained variances in the models reveals that customer loyalty in Segment 2 is much better explained by the two independent variables $\left(R^{2}=0.559\right)$ than customer loyalty in Segment $1\left(\mathrm{R}^{2}=0.273\right)$. 


\section{Discussion}

The aim of this study was to investigate the RM strategy of a case bank and to analyse whether its implementation resulted in relationship satisfaction and customer-perceived improvements in the bank relationship, thereby increasing loyalty. The most profitable customer segment is small but important to the bank. Therefore, the bank has paid particular attention to the needs and wishes of these customers compared with those of other customer groups. Consequently, it was expected that Segment 1 customers would experience relationship improvements and that the improvements would be reflected in higher loyalty. However, this was not the case.

The case bank's relationship marketing strategy, with the intention of a customer oriented focus on Segment 1 customers, did not lead to higher loyalty in Segment 1 customers compared with Segment 2 customers, who were supposed to receive a sales oriented treatment. No significant differences were found between the two groups on any of the relationship strength items: relationship satisfaction, relationship improvement or loyalty. Furthermore, relationship satisfaction and relationship improvement explained a relatively small amount of the variance in customer loyalty in Segment 1.

There are several explanations for these findings. One possibility is that customers of different segments give different meaning to, for example, what it takes to experience relationship satisfaction. Profitable customers are likely to be aware of their worth to the bank, and thus have a smaller tolerance for anything less than excellent service. They are likely to be more demanding and might more easily feel that the service falls short of their high expectations. Although they receive more personal attention, they may perceive few other benefits in the relationship. When most transactions can be performed as self-services, service improvement and relationship marketing efforts may need to be directed towards filling technological gaps (Lang \& Colgate, 2003), and facilitating technological relationships. Furthermore, it is 
possible that other factors, not included in the current study, would have been better at explaining the loyalty behaviour of the most profitable customers. Such variables include, for example, customers' service involvement, their competing banking relationships at other banks and core service perceptions. Answers to the open-ended question also indicated the existence of additional customer concerns.

Based on the freely formulated customer comments, price issues related to fees and interest rates were predominantly a concern for customers in Segment 2, whereas only Segment 1 customers made complaints regarding the complexity or inadequacy of the bonus programme. Segment 1 customers have the greatest earnings potential from the bonus programme, since it is based on the customers' volume of business. The programme was revised in the same year as this study was conducted.

With regard to what Segment 1 customers might lack in their banking relationship, several customers suggested "investment evenings", where they could receive information about the different options available for the investment of their money. Although this would require extra time and resources, it would potentially improve the relationships with those valued customers who otherwise do not have time to visit the bank and who conduct most or all of their business with the bank over the Internet.

Both Segment 1 and Segment 2 customers added positive comments concerning the friendly and personal service during encounters with bank employees. This indicates that the customer oriented attitude is not limited to the employees' interactions with Segment 1 customers. The questionnaire admittedly did not test for differences in perceived customer/sales orientation between the segments. However, if both segments indeed perceive the employees to be customer oriented, it could explain why no significant differences were found between the segments. Although such a situation does not fit in with the bank's strategy, it can hardly be seen as a failure. As long as Segment 1 customers perceive that they are prioritised and the 
volume of Segment 2 customers' banking affairs is increased, a general customer oriented atmosphere can only be commended. However, since Segment 1 customers may have higher expectations with regards to being treated in a customer oriented way, it is possible that improvements in the Segment 1 relationships compared to Segment 2 relationships are nullified by the higher expectations of the more profitable customers. Hence, the difference would not be observable in the responses to the questionnaire.

Another possibility is that customers, managers, and employees have different views of how relationship marketing should be conducted. Activities that are viewed as extremely customer oriented from the bank management's point of view, such as actively contacting customers, offering them personal meetings, and mapping their needs on a continual basis, may be viewed by the customer as normal services offered by, or expected from, any bank. Furthermore, the changes that have occurred in Segment 1 customers' banking relationships over the past four to five years, although positive, may be viewed as relatively insignificant when placed in the perspective of the customers' entire relationship history with the bank.

\section{Managerial implications}

The positive effects of a relationship marketing strategy on customer-perceived relationship satisfaction and loyalty have not been confirmed in this study. However, the results seem to indicate that the case bank is pursuing a worthwhile strategy since the levels of perceived customer relationship satisfaction and loyalty are relatively high and the customers have perceived improvements in the banking relationship since the RM strategy was launched. Consequently, the adoption of a customer oriented strategy has delivered positive intangible returns, in addition to providing a beneficial spill over effect on a less profitable segment of customers, which was intended to be the receiver of a sales oriented approach. On the other hand, the implemented RM strategy was not sufficient to improve customer relationship 
strength in Segment 1 compared with Segment 2 and, therefore, the bank should review its current strategy for possible weaknesses.

Branch managers constantly have to balance between marketing services to new customers and investing in relationship marketing to retain existing customers, with limited resources (Carson et al., 2004). Role conflicts and role stress may result as employees are asked to manage individual customers of different profitability segments with different communication strategies. The implementation of such strategies is particularly difficult when customers are unaware of their (changing) profitability status within the bank. This makes it impossible to direct customers to different tellers, or contact persons. The personnel need to be willing and able to communicate with all customer segments according to the chosen strategy. Although internal marketing (Ballantyne, 2003; Berry, 1981; O’Loughlin and Szmigin, 2005) can be used to reduce employee discomfort and to increase their understanding of and commitment to the RM segmentation strategy, a completely new model of relationship management, with new ways of contacting and interacting with customers may be needed.

Based on a study of banks and their small business customers, Colgate and Lang (2005) point out that the establishment of a relationship orientation is only a first step; if relationship quality is to be improved, necessary resources and motivation on the bank's part are crucial to ensure successful execution of a relationship strategy. Furthermore, although the aim is to build relationships with selected customers in order to retain them, organisational systems and structures may be configured to support transactional exchange (Farquhar, 2004). As outlined by Payne and Frow (2005), customer relationship management involves a series of processes, which need to be integrated within the firm in order to succeed.

Overall, a customer oriented strategy is desirable within retail banking, but the question remains as to what the differential drivers of loyalty are across profitability segments. By identifying the aspects of a banking relationship that are more highly valued among the 
different segments, bank managers would be able to devise appropriate strategies, and allocate resources efficiently.

\section{Limitations}

The study has a number of limitations, which affect its generalisability. It was conducted as a case study of one specific branch of the OP Bank Group in Finland, which limits the external validity of the results. The fact that the case bank is relatively small and located in a semirural area might affect the nature of customer relationships, in that it may be easier to develop closer relationships than in an urban setting.

In addition, self-selection bias cannot be ruled out. The high means indicate that there may have been a self-selection among particularly satisfied customers to participate in the study. However, as past research shows, customer satisfaction does not guarantee loyalty, and selfselection cannot completely explain the differences between the two segments regarding the effect of relationship satisfaction on loyalty.

A limitation of the study is also that we were not able to ascertain if, or to what extent, customers belonging to Segment 1 had received the intended RM treatment. We can only say that the bank's strategic intent was to treat the customers in a certain way and our study shows that the implemented strategy may not have had the intended effect.

The study was also limited by explaining loyalty with only the abstract, latent constructs of relationship satisfaction and improvement. Customer satisfaction and loyalty are affected also by other factors, such as the price of services, or the number and severity of negative critical incidents. Furthermore, the study did not take customers' past behaviour towards banks into account. Ganesh et al. (2000) found that dissatisfied customers who have switched service providers appear to differ significantly from other types of customers with regards to satisfaction and loyalty behaviours. Future research should include more antecedents of 
customer loyalty and switching behaviour and, in particular, explore the antecedents of loyalty in the most profitable segment.

Finally, considering the lack of significant differences in the responses of customers belonging to Segment 1 and Segment 2, it would have been essential to also include Segment 3 customers in order to assess if they differed significantly from the other segments. The primary reason for omitting them from the study was that they were not considered to be of strategic interest to the bank, due to their lack of profitability. As emphasised by Kumar et al. (2003, p. 668), any company needs transactional customers in order to maintain stable cash flows, even if they are only marginally profitable. However, investments should not be made in these relationships unless they exhibit profit potential (Reinartz and Kumar, 2000). In line with this, the bank has adopted an approach for Segment 3 based on cost-cutting and, when possible, increasing share-of-wallet.

Despite these considerations, the study should be viewed as a step towards filling the gap in marketing research resulting from the lack of studies investigating the effect of a particular relationship marketing strategy on perceived relationship satisfaction improvements and loyalty in different customer profitability segments.

\section{Suggestions for further research}

In addition to the suggestions put forth in the discussion above, there is a general need for more research on RM strategies and their actual effects on customer relationship strength. However, more effort should also be given to studying customers' desire, or lack of it, for maintaining close customer relationships with service providers. Too little is still known regarding the nature of customer relationships, what modern customers expect from their service provider relationships, what forms these relationships take, and how they differ between profitability segments. 
RM strategies aim at increasing customers' commitment to the service provider and, thereby, increasing their share-of-wallet through cross-selling activities. This was also the strategy of the focal bank. However, our study did not include measures on customers' intentions to invest in more of the bank's services, and with a few recent exceptions (Bolton et al., 2004; Li et al., 2005; Prinzie and Van den Poel, 2006; Reinartz and Kumar, 2003), very little attention has been given to customers' cross-buying behaviour. It would be of interest to study, for example, the differences in cross-buying behaviour between different profitability and loyalty segments, and the effect of relationship marketing activities on cross-buying behaviour. In addition, more in-depth studies are needed to understand differences between service provider and customer views of relationships, and to gain better knowledge of how front-line employees cope with having to develop different types of relationships with different customer groups. Furthermore, although both the internal (employee oriented) and external (customer oriented) links of Heskett et al.'s (1997) service-profit chain have been examined

in the retail banking sector (Gelade and Young, 2005; Loveman, 1998), future research should seek to provide definitive empirical evidence of an entire chain of effects, resulting specifically from the implementation of a relationship marketing strategy.

\section{Notes}

1. Although the segmentation criteria for the three segments would become much clearer if the exact amounts of volume, profitability and wealth levels were displayed, this can unfortunately not be done due to reasons of confidentiality. 


\section{References}

Abdul-Muhmin, A.G. (2002), "Effects of suppliers' marketing program variables on industrial buyers' relationship satisfaction and commitment", Journal of Business and Industrial Marketing, Vol. 17 No. 7, pp. 637-651.

Abratt, R. and Russell J. (1999), "Relationship Marketing in Private Banking in South Africa", International Journal of Bank Marketing, Vol. 17 No. 1, pp. 5-19.

Åkerlund, H. (2004), Fading customer relationships. Doctoral thesis No. 132, Swedish School of Economics and Business Administration, Helsinki.

Aldlaigan, A. and Buttle, F. (2005), "Beyond satisfaction: customer attachment to retail banks", International Journal of Bank Marketing, Vol. 23 No. 4, pp. 349-359.

Anderson, E.W., Fornell, C. and Lehmann, D.R. (1994), "Customer Satisfaction, Market Share, and Profitability: Findings from Sweden", Journal of Marketing, Vol. 58 No. 3, pp. 5366.

Anderson, E.W. and Mittal, V. (2000), “Strengthening the Satisfaction-Profit Chain”, Journal of Service Research, Vol. 3 No. 2, pp. 107-120.

Athanassopoulos, A., Gounaris, S. and Strathakopoulos, V. (2001), "Behavioural responses to customer satisfaction: an empirical study", European Journal of Marketing, Vol. 35 No. 5/6, pp. 687-707.

Ballantyne, D. (2003), “A relationship-mediated theory of internal marketing”, European Journal of Marketing, Vol. 37 No. 9, pp. 1242-1260.

Barnes, J.G. and Howlett, D.M. (1998), "Predictors of equity in relationships between financial services providers and retail customers", International Journal of Bank Marketing, Vol. 16 No. 1, pp. 15-23. 
Baumann, C., Burton, S. and Elliott, G. (2005), "Determinants of customer loyalty and share of wallet in retail banking", Journal of Financial Services Marketing, Vol. 9 No. 3, pp. 231248.

Bejou, D., Ennew, C.T. and Palmer, A. (1998), "Trust, ethics and relationship satisfaction”, International Journal of Bank Marketing, Vol. 16 No. 4, pp. 170-175.

Bejou, D, Wray, B. and Ingram, T.N. (1996), "Determinants of Relationship Quality: An Artificial Neural Network Analysis”, Journal of Business Research, Vol. 36 No. 2, pp. 137143.

Bennett, R. and Rundle-Thiele, S. (2004), "Customer satisfaction should not be the only goal”, Journal of Services Marketing, Vol. 18 No. 7, pp. 514-523.

Berry, L.L. (1981), “The employee as customer”, Journal of Retail Banking, Vol. 3 No. 1, pp. $25-28$.

Berry, L.L. (1983), “Relationship Marketing”, in Berry, L.L., Shostack, G.L. and Upah, G.D. (eds.), Emerging Perspectives on Services Marketing, Proceedings Series, American Marketing Association, Chicago, IL., pp. 25-28.

Berry, L.L. (1995), “Relationship Marketing of Services - Growing Interest, Emerging Perspectives”, Journal of the Academy of Marketing Science, Vol. 23 No. 4, pp. 236-245. Bitner, M.J. and Hubbert, A.R. (1994), "Encounter Satisfaction Versus Overall Satisfaction Versus Quality: The Customers Voice”, in Rust, R.T. and Oliver, R.L. (eds.), Service Quality: New Directions in Theory and Practice. Sage Publications, Inc., London, pp. 79-94.

Bloemer, J., de Ruyter, K. and Peeters, P. (1998), "Investigating drivers of bank loyalty: the complex relationship between image, service quality and satisfaction", International Journal of Bank Marketing, Vol. 16 No.7, pp. 276-286. 
Bolton, R.N., Kannan, P.K. and Bramlett, M.D. (2000), "Implications of Loyalty Program Membership and Service Experiences for Customer Retention and Value", Journal of the Academy of Marketing Science, Vol. 28 No. 1, pp. 45-65.

Bolton, R.N., Lemon, K.N. and Verhoef, P.C. (2004), “The Theoretical Underpinnings of Customer Asset Management: A Framework and Propositions for Future Research", Journal of the Academy of Marketing Science, Vol. 32 No. 3, pp. 271-292.

Carson, D., Gilmore, A. and Walsh, S. (2004), "Balancing transaction and relationship marketing in retail banking", Journal of Marketing Management, Vol. 20 No. 3/4, pp. 431455.

Clark, M. (1997), "Modelling the impact of customer-employee relationships on customer retention rates in a major UK retail bank", Management Decision, Vol. 35 No. 4, pp. 293-301. Colgate, M. and Hedge, R. (2001), “An investigation into the switching process in retail banking services", International Journal of Bank Marketing, Vol. 19 No. 5, pp. 201-212. Colgate, M. and Lang, B. (2005), "Positive and negative consequences of a relationship manager strategy: New Zealand banks and their small business customers", Journal of Business Research, Vol. 58 No. 2, pp. 195-204.

Crosby, L.A., Evans, K.R. and Cowles, D. (1990), "Relationship Quality in Services Selling: An Interpersonal Influence Perspective”, Journal of Marketing, Vol. 54 No. 3, pp. 68-81. Dabholkar, P.A. (1995), “The convergence of customer satisfaction and service quality evaluations with increasing customer patronage", Journal of Consumer Satisfaction, Dissatisfaction and Complaining Behavior, Vol. 8, pp. 32-43.

Dick, A.S. and Basu, K. (1994), “Customer Loyalty: Toward an Integrated Conceptual Framework", Journal of the Academy of Marketing Science, Vol. 22 No. 2, pp. 99-113. Dowling, G.W. and Uncles, M. (1997), “Do Customer Loyalty Programs Really Work?”, Sloan Management Review, Vol. 38 No. 4, pp. 71-82. 
Dwyer, R.F., Schurr, P.H. and Oh, S. (1987), "Developing Buyer-Seller Relationships", Journal of Marketing, Vol. 51 No. 2, pp. 11-27.

Eisenhardt, K.M. (1989), “Building Theories from Case Study Research”, Academy of Management Review, Vol. 14 No. 4, pp. 532-550.

Ennew, C.T. and Binks, M.R. (1996), "Good and bad customers: the benefits of participating in the banking relationship", International Journal of Bank Marketing, Vol. 14 No. 2, pp. 513.

Ennew, C.T. and Binks, M.R. (1999), "Impact of Participative Service Relationships on Quality, Satisfaction and Retention: An Exploratory Study", Journal of Business Research, Vol. 46 No. 2, pp. 121-132.

Farquhar, J.D. (2004), “Customer retention in retail financial services: an employee perspective", International Journal of Bank Marketing, Vol. 22 No. 2, pp. 86-99. Fink, A. (1995), The Survey Handbook, Sage Publications, Inc., Thousand Oaks, CA. Ganesh, J., Arnold, M.J. and Reynolds, K.E. (2000), "Understanding the Customer Base of Service Providers: An Examination of the Differences Between Switchers and Stayers", Journal of Marketing, Vol. 64 No. 3, pp. 65-87.

Gelade, G.A. and Young, S. (2005), "Test of a service profit chain model in the retail banking sector", Journal of Occupational and Organizational Psychology, Vol. 78 No. 1, pp. 1-22. Grönroos, C. (1994), “From Marketing Mix to Relationship Marketing: Towards a Paradigm Shift in Marketing”, Management Decision, Vol. 32 No. 2, pp. 4-20.

Gummesson, E. (1994), "Broadening and Specifying Relationship Marketing”, Asia-Australia Marketing Journal, Vol. 2 No. 1, pp. 31-43.

Hair, Jr., J.F, Anderson, R.E., Tatham, R.L. and Black, W.C. (1998), Multivariate Data Analysis, Fifth Edition, Prentice-Hall International, Inc., Upper Saddle River, N.J. 
Hallowell, R. (1996), “The relationships of customer satisfaction, customer loyalty, and profitability: an empirical study", International Journal of Service Industry Management, Vol. 7 No. 4, pp. 27-42.

Heskett, J.L., Sasser, Jr., W.E. and Schlesinger, L.A. (1997), The Service Profit Chain: How leading companies Link Profit and Growth to Loyalty, Satisfaction, and Value, The Free Press, New York, NY.

Hooi Ting, D. (2004), "Service quality and satisfaction perceptions: curvilinear and interaction effect”, International Journal of Bank Marketing, Vol. 22 No. 6, pp. 407-420. Jamal, A. and Naser, K. (2002), “Customer satisfaction and retail banking: an assessment of some of the key antecedents of customer satisfaction in retail banking", International Journal of Bank Marketing, Vol. 20 No. 4/5, pp. 146-161.

Kaiser, H.F. and Rice, J. (1974), "Little Jiffy Mark IV”, Educational and Psychological Measurement, Vol. 34, Spring, pp. 111-117.

Keiningham, T.L., Perkins-Munn, T. and Evans, H. (2003), “The Impact of Customer Satisfaction on Share-of-Wallet in a Business-to-Business Environment", Journal of Service Research, Vol. 6 No. 1, pp. 37-50.

Keltner, B. (1995), "Relationship Banking and Competitive Advantage: Evidence from the U.S. and Germany", California Management Review, Vol. 37 No. 4, pp. 45-72.

Kumar, V., Bohling, T.R. and Ladda, R.N. (2003), “Antecedents and consequences of relationship intention: Implications for transaction and relationship marketing”, Industrial Marketing Management, Vol. 32 No. 8, pp. 667-676.

Lang, B. and Colgate M. (2003), "Relationship Quality, On-line Banking and the Information Technology Gap”, International Journal of Bank Marketing, Vol. 21 No. 1, pp. 29-37. 
Li, S., Sun, B. and Wilcox, R.T. (2005), "Cross-selling sequentially ordered products: an application to consumer banking services", Journal of Marketing Research, Vol. 42 No.2, pp. 233-239.

Liljander, V. and Roos, I. (2002), “Customer Relationship Levels: From Spurious to True Relationships”, Journal of Services Marketing, Vol. 16 No.7, pp. 593-614.

Liljander, V. and Strandvik, T. (1995), "The Nature of Customer Relationships in Services", in Swartz, T. A., Bowen, D. E. and Brown, S. W. (Eds.), Advances in Services Marketing and Management (Vol. 4, pp. 141-167), JAI Press Inc., London.

Loveman, G.W. (1998), “Employee Satisfaction, Customer Loyalty, and Financial Performance. An Empirical Examination of the Service Profit Chain in Retail Banking”, Journal of Service Research, Vol. 1 No. 1, pp. 18-31.

Madill, J.J., Feeney, L., Riding, A. and Haines, G.H.J. (2002), “Determinants of SME owners' satisfaction with their banking relationships: a Canadian study", International Journal of Bank Marketing, Vol. 20 No. 2, pp. 86-98.

Mazursky, D. and Geva, A. (1989), “Temporal Decay in Satisfaction - Purchase Intention Relationship", Psychology and Marketing, Vol. 6 No. 3, pp. 211-227.

Michel, S. (2004), “Consequences of perceived acceptability of a bank’s service failures”, Journal of Financial Services Marketing, Vol. 8 No. 4, pp. 367-377.

Mittal, V., Kumar, P. and Tsiros, M. (1999), ”Attribute-Level Performance, Satisfaction, and Behavioral Intentions over Time: A Consumption System Approach”, Journal of Marketing, Vol. 63 No. 2, pp. 88-101.

Naidu, G.M., Parvatiyar, A., Sheth, J.N. and Westgate, L. (1999), "Does Relationship Marketing Pay? An Empirical Investigation of Relationship Marketing Practices in Hospitals", Journal of Business Research, Vol. 46 No. 3, pp. 207-218. 
Nordman, C. (2004), Understanding Customer Loyalty and Disloyalty - The Effect of Loyalty-supporting and-repressing Factors, Doctoral thesis No. 125, Swedish School of Economics and Business Administration, Helsinki, Finland.

Oliver, R.L. (1999), “Whence Consumer Loyalty”, Journal of Marketing, Vol. 63 No. 4 (special issue), pp. 33-44.

O’Loughlin, D. and Szmigin, I. (2005), "External and internal accountability of financial services suppliers: current paradoxes in managing expectations and experience", Journal of Strategic Marketing, Vol. 13 No. 2, pp. 133-147.

O’Loughlin, D., Szmigin, I. and Turnbull, P. (2004), “From Relationships to Experiences in Retail Financial Services", International Journal of Bank Marketing, Vol. 22 No. 7, pp. 522539.

O’Malley, L. and Tynan, C. (2000), 'Relationship Marketing in Consumer Markets. Rhetoric or Reality?”, European Journal of Marketing, Vol. 34 No. 7, pp. 797-815.

Osuuspankkilehti (1997), Osuuspankkiryhmän ammattilehti, kesäkuu (June). The OP Bank Group's trade magazine.

Palmatier, R.W. and Gopalakrishna, S. (2005), "Determining the Payoff from Relationship Marketing Programs", MSI Reports: Marketing Science Institute Working Paper Series, Issue 1 No. 05-001, Report No. 05-102, pp. 49-70.

Paulin, M., Perrien, J., Ferguson, R.J., Salazar, A.M.A. and Seruya, L.M. (1998), "Relational norms and client retention: external effectiveness of commercial banking in Canada and Mexico", International Journal of Bank Marketing, Vol. 16 No. 1, pp. 24-31.

Payne, A. and Frow, P. (2005), “A strategic framework for customer relationship management", Journal of Marketing, Vol. 69 No. 4, pp. 167-176.

Perkins-Munn, T., Aksoy, L., Keiningham, T.L. and Estrin, D. (2005), “Actual Purchase as a Proxy for Share of Wallet", Journal of Service Research, Vol. 7 No. 3, pp. 245-256. 
Peterson, R.A. (2000), Constructing Effective Questionnaires, Sage Publications, Inc., Thousand Oaks, CA.

Pont, M. and McQuilken, L. (2005), “An empirical investigation of customer satisfaction and loyalty across two divergent bank segments", Journal of Financial Services Marketing, Vol. 9 No. 4, pp. 344-359.

Prinzie, A. and Van den Poel, D. (2006), "Investigating purchasing-sequence patterns for financial services using Markov, MTD and MTDg models", European Journal of Operational Research, Vol. 170 No. 3, pp. 710-734.

Ravald, A. and Grönroos, C. (1996), “The value concept and relationship marketing”, European Journal of Marketing, Vol. 30 No. 2, pp. 19-30.

Reichheld, F.F. (1996), The Loyalty Effect, Harvard Business School Press, Boston, MA. Reinartz, W.J. and Kumar, V. (2000), “On the Profitability of Long-Life Customers in a Noncontractual Setting: An Empirical Investigation and Implications for Marketing”, Journal of Marketing, Vol. 64 No. 4, pp. 17-35.

Reinartz, W.J. and Kumar, V. (2002), “The Mismanagement of Customer Loyalty”, Harvard Business Review, Vol. 80 No. 7, pp. 4-12.

Reinartz, W.J. and Kumar, V. (2003), “The Impact of Customer Relationship Characteristics on Profitable Lifetime Duration”, Journal of Marketing, Vol. 67 No. 1, pp. 77-99.

Roberts, K., Varki, S. and Brodie, R. (2003), "Measuring the quality of relationships in consumer services: an empirical study”, European Journal of Marketing, Vol. 37 No. 1/2, pp.169-196.

Rosen, D.E. and Surprenant, C. (1998), "Evaluating relationships: are satisfaction and quality enough?”, International Journal of Service Industry Management, Vol. 9 No. 2, pp. 103-125. Saxe, R. and Weitz, B.A. (1982), "The SOCO Scale: A Measure of the Customer Orientation of Salespeople”, Journal of Marketing Research, Vol. 19 No. 3, pp. 343-351. 
Sharp, B. and Sharp, A. (1997), "Loyalty Programs and Their Impact on Repeat-Purchase Loyalty Patterns”, International Journal of Research in Marketing, Vol. 14 No. 5, pp. 473 486.

Sheth, J.N. and Parvatiyar, A. (2000), “The Evolution of Relationship Marketing”, in Sheth, J.N. and Parvatiyar, A. (eds.), Handbook of Relationship Marketing, Sage Publications, Inc., London, pp. 119-148.

Silvestro, R. and Cross, S. (2000), “Applying the service profit chain in a retail environment: Challenging the 'satisfaction mirror'”, International Journal of Service Industry Management, Vol. 11 No. 3, pp. 244-268.

Smith, W.R. (1956), "Product differentiation and market segmentation as alternative marketing strategies", Journal of Marketing, Vol. 21 No. 1, pp. 3-8.

Stauss, B., Schmidt, M. and Schoeler, A. (2005), "Customer frustration in loyalty programs", International Journal of Service Industry Management, Vol. 16 No. 3, pp. 229-252.

Storbacka, K. (1994), The Nature of Customer Relationship Profitability: Analysis of Relationships and Customer Bases in Retail Banking, Doctoral thesis No. 55, Swedish School of Economics and Business Administration, Helsinki.

Storbacka, K. (1997), “Segmentation Based on Customer Profitability - Retrospective Analysis of Retail Bank Customer Bases”, Journal of Marketing Management, Vol. 13 No. 5, pp. 479-492.

Sweeney, A. and Morrison, M. (2004), “Clicks vs. Bricks: Internet-facilitated relationships in Financial Services", International Journal of Internet Marketing and Advertising, Vol. 1 No. 4, pp. 350-370.

Verhoef, P.C. (2003), "Understanding the Effect of Customer Relationship Management Efforts on Customer Retention and Customer Share Development", Journal of Marketing, Vol. 67 No. 4, pp. 30-45. 
Verhoef, P.C., Franses, P.H. and Donkers, B. (2002), “Changing Perceptions and Changing Behavior in Customer Relationships”, Marketing Letters, Vol. 13 No. 2, pp. 121-134.

Walsh, S., Gilmore, A. and Carson, D. (2004), "Managing and implementing simultaneous transaction and relationship marketing", International Journal of Bank Marketing, Vol. 22 No. 7 , pp. 468-483.

Yavas, U., Benkenstein, M. and Sthuldreier, U. (2004), "Relationships between service quality and behavioral outcomes: A study of private bank customers in Germany”, International Journal of Bank Marketing, Vol. 22 No. 2, pp. 144-157.

Zeithaml, V.A., Rust, R.T. and Lemon, K.N. (2001), “The customer pyramid: Creating and serving profitable customers", California Management Review, Vol. 43 No. 4, pp. 118-142. 
Table I.

Respondent profiles in segments

\begin{tabular}{lccc}
\hline Characteristics & \multicolumn{3}{c}{ Number (and Percentage) by segment and in total } \\
\hline Age & Segment $~$ & Segment 2 & Total \\
$20-34$ & $24(16.4)$ & $21(12.1)$ & $45(14.1)$ \\
$35-49$ & $46(31.5)$ & $45(26.0)$ & $91(28.5)$ \\
$50-64$ & $47(32.2)$ & $58(33.5)$ & $105(32.9)$ \\
65 years and over & $29(19.9)$ & $49(28.3)$ & $78(24.5)$ \\
Mean average (in years) & 50.48 & 53.76 & 52.26 \\
Standard deviation & 14.64 & 14.97 & 14.89 \\
& & & \\
Gender & & & \\
Male & $90(61.6)$ & $85(49.1)$ & $175(54.9)$ \\
Female & $56(38.4)$ & $88(50.9)$ & \\
& & & \\
Relationship length & & & \\
4-10 years & $23(15.7)$ & $20(11.6)$ & $43(13.5)$ \\
11-20 years & $42(28.8)$ & $50(28.9)$ & $92(28.8)$ \\
21-30 years & $32(21.9)$ & $55(31.8)$ & $87(27.3)$ \\
more than 30 years & $49(33.6)$ & $48(27.7)$ & $97(30.4)$ \\
Mean average (in years) & 26.44 & 26.19 & 26.30 \\
Standard deviation & 14.00 & 12.59 & 13.23 \\
\hline
\end{tabular}


Table II.

Item means, factors, and reliability coefficients for the retained items

\begin{tabular}{|c|c|c|}
\hline Constructs and items & $\begin{array}{l}\text { Mean } \\
(\mathrm{N}=319)\end{array}$ & $\begin{array}{l}\text { St. } \\
\text { dev. }\end{array}$ \\
\hline \multicolumn{3}{|l|}{ Customer relationship satisfaction, Cronbach's $\alpha=0.719$} \\
\hline (1) I am satisfied with the quality of the OP Bank's services. * & 4.29 & 0.66 \\
\hline (2) I am satisfied with the OP Bank's bonus programme. * & 3.75 & 0.94 \\
\hline (3) When I have experienced unforeseen or critical situations, the OP & 3.89 & 0.89 \\
\hline Bank has managed these in a satisfactory manner. * & & \\
\hline $\begin{array}{l}\text { (4) I am satisfied with the interactions that I have had with the OP } \\
\text { Bank. * }\end{array}$ & 4.38 & 0.73 \\
\hline (5) I trust that the OP Bank informs me about new services/products. * & 4.13 & 0.77 \\
\hline (6) The OP Bank satisfies my needs. & 4.22 & 0.73 \\
\hline (7) The OP Bank understands my needs. & 3.90 & 0.82 \\
\hline \multicolumn{3}{|l|}{ Relationship improvement, Cronbach's $\alpha=0.789$} \\
\hline $\begin{array}{l}\text { (8) The quality of the OP Bank's services has improved over the past } \\
4-5 \text { years. }\end{array}$ & 3.67 & 0.84 \\
\hline $\begin{array}{l}\text { (9) I am satisfied with the changes that have occurred in my } \\
\text { relationship with the OP Bank over the past } 4-5 \text { years. * }\end{array}$ & 3.89 & 0.85 \\
\hline $\begin{array}{l}\text { (10) My overall satisfaction with the OP Bank has increased over the } \\
\text { past 4-5 years. * }\end{array}$ & 3.63 & 0.88 \\
\hline $\begin{array}{l}\text { (11) I have become more loyal towards the OP Bank over the past 4-5 } \\
\text { years. * }\end{array}$ & 3.45 & 1.04 \\
\hline \multicolumn{3}{|l|}{ Customer loyalty, Cronbach's $\alpha=0.783$} \\
\hline (12) I have never seriously considered changing banks. * & 3.90 & 1.19 \\
\hline (13) I consider myself to be a loyal customer of the OP Bank. * & 4.25 & 0.83 \\
\hline (14) I conduct all my banking affairs at the OP Bank. * & 4.11 & 1.17 \\
\hline (15) I would recommend the OP Bank to friends and acquaintances. * & 4.21 & 0.81 \\
\hline
\end{tabular}

* Denotes the items that were retained after factor analysis 
Table III.

Loyalty regressed on relationship satisfaction and relationship improvement in Segment 1 and Segment 2

\begin{tabular}{llllll}
\hline Dependent variable & Independent variables & Std. $\beta$ coeff. & p-value & $\mathrm{R}^{2}$ & F-value \\
\hline$\underline{\text { Segment 1 }}$ & $\begin{array}{l}\text { Customer relationship } \\
\text { satisfaction }\end{array}$ & 0.425 & 0.000 & 0.273 & 26.854 \\
& $\begin{array}{l}\text { Relationship } \\
\text { improvement }\end{array}$ & 0.332 & 0.000 & & \\
\hline Segment 2 & $\begin{array}{l}\text { Customer relationship } \\
\text { Customer loyalty }\end{array}$ & 0.656 & 0.000 & 0.559 & 107.715 \\
& $\begin{array}{l}\text { Selationship } \\
\text { improvement }\end{array}$ & 0.335 & 0.000 & & \\
\hline
\end{tabular}

